УДК 321.01

\title{
ГОСУДАРСТВЕННОСТЬ ПРИДНЕСТРОВЬЯ: ИНТЕРПРЕТАЦИЯ АКТУАЛЬНЫХ ТЕНДЕНЦИЙ В СВЕТЕ ИДЕЙ О СОЦИАЛЬНОМ КАПИТАЛЕ ГРАЖДАНСКОГО ОБЩЕСТВА
}

\author{
Короткова Ольга Александровна \\ преподаватель кафедры сочиологии и сочиальных технологий \\ Приднестровского государственного университета им. Т.Г. Шевченко, \\ Приднестровская Молдавская Республика \\ (3300г., Молдова, Тирасполь, ул. 25 Октября, 107)
}

\section{STATEHOOD OF TRANSNISTRIA: INTERPRETATION OF CURRENT TRENDS IN THE LIGHT OF IDEAS ABOUT THE SOCIAL CAPITAL OF CIVIL SOCIETY}

Автор рассматривает социальный и человеческий капитал, раскрывая роль государственно-общественного диалога на примере самоопределившейся (непризнанной) Приднестровской Молдавской Республики.

Author considers social and human capital as potential resources and a necessary condition for the development of socio-political life and reveals the role of state-public dialogue using the example of the Pridnestrovian Moldavian Republic (a self-determined but unrecognized state).

Ключевые слова: государственно-общественный диалог, государство, гражданское общество, социальный и человеческий капитал, Приднестровская Молдавская Республика.

Key words: state-public dialogue, state, civil society, social and human capital, human capital, Pridnestrovian Moldavian Republic.

Распад СССР и изменение политических ожиданий и настроений в обществе, повлекли за собой выход из состава МССР левобережной части территории и провозглашение Приднестровской Молдавской Республики. Это преобразование выразилось в системной трансформации институциональной и социально-групповой структуры гражданского общества, а также качественном преобразовании института власти из периферийного в самостоятельный, формирование которого происходило на фоне становления непризнанного государства. У местных представителей гражданского общества ярко выражалось стремление к политической самостоятельности, характеризующееся оппозиционностью по отношению к политическому курсу Республики Молдова.

Именно социальный капитал дал толчок развитию гражданского общества, мобилизации населения, развивавшегося параллельно со становлением республики, ее институтов и политической системы. Приднестровская Молдавская Республика была создана «по инициативе снизу, в результате общественного договора основных социальных, национальных и религиозных групп региона, которых объединила борьба за создание собственного государства» [1].

Понятие «социальный капитал» ввел Пьер Бурдьё в статье «Формы капитала», обозначив, таким образом, социальные связи, которые могут выступать ресурсом для получения выгод [2]. Этот термин французский социолог представляет как «агрегацию действительных или потенциальных ресурсов, связанных с включениями в прочные сетевые или более или менее институционализированные отношения взаимных обязательств или признаний $<\ldots>$ выгоду, которая аккумулируется благодаря членству в группе и является базисом возможной солидарности» [там же].

Р. Патнэм идею социального капитала измерял с помощью индивидуальных индикаторов, таких, как: интенсивность, сила контактов, членство в общественных организациях, а также доверие между соседями и социальными институтами. Социальный капитал - одна из характеристик социальной организации, такая же, как доверие, нормы, которые способны повысить действенность общества [3]. Индивиды, фирмы, районы будут процветать в том случае, если доверие и социальные сети хорошо развиты [4], следовательно, социальный капитал и гражданское общество - предшественники общественного благосостояния.

Поскольку социальный капитал - источник нематериальной власти, а, следовательно, и влияния, то в своей книге «Демократия в Америке» А. де Токвиль, концентрирует своё внимание именно на социальном капитале, хотя данный термин ввели в обиход спустя 150 лет. Так, будучи в США в 30-е годы XIX века, Токвиль отметил, что американцы используют «искусство объединения», в отличие от его французских сограждан. Американцы объединяются в различные сообщества: литературные, религиозные, а так же, особо актуальные в то время, борьбы с рабством.

Таким образом, по его мнению, «слабые» люди, заинтересованные в достижении определенной цели, объединившись, проходили «школу американской демократии». Мы можем предположить, что именно социальный капитал в подобной форме способствовал созданию дополнительных моральных догм, которые 
сделали демократию возможной.

Во многом именно благодаря рабочему движению - организации трудовых коллективов трудящихся, возникшем в 1989 году, общественным организациям, принимавшим самое активное участие в деле защиты самоопределившейся республики от агрессивных действий со стороны Молдовы, как то: конференции и съезды общественных движений (Объединенного Совета Трудовых Коллективов (ОСТК), женского забастовочного движения и ряда других) и массовым митингам, продемонстрировавшим потенциал гражданского общества левобережья МССР, существует сегодня Приднестровская Молдавская Республика.

Подобное понимание сущности проблематики социального капитала послужило основой для более детальной и осмысленной работы для других учёных над её решением в течение последних десятилетий. Учитывая вышеизложенное, мы также можем констатировать, что налицо сближение социологических и экономических теорий: социальный капитал способствует образованию связей между людьми, обусловленных процессом их взаимодействия в социальных полях, и, более того, обладает способностью аккумулироваться. Закономерным становится вопрос, какими свойствами капитала наделены современные гражданские отношения?

Участвуя в гражданских отношениях, люди всё чаще ищут, и даже ждут, какой-либо выгоды или благ, при этом само участие для них представляет небольшую ценность, разве что в качестве «галочки» для резюме. Вслед за Фердинандом Тённисом, который в своей работе «Общность и общество» отмечал, что «в сложных обществах социальные связи становятся предметом целевого построения и манипуляций, направленных на извлечение личной выгоды» [6], мы можем говорить о том, что социальные, иными словами, гражданские отношения, имеют инструментальный характер.

Жизнь современного человека формализирована и заключена в организованные формы, характеризующиеся и наличием систем кодификации, и регламентом, т.е. она протекает в рамках строго заданных параметров, и мы можем говорить о том, что социальные отношения основаны на нормативном регулировании.

Эффективность социальных отношений базируется на основе социального порядка / безопасности / доверии.

Западные социологи рассматривают активное вовлечение населения в жизнь гражданского общества и непосредственное решение его проблем, как специфический вид социального капитала - потенциалом взаимного доверия и взаимопомощи.

В широком употреблении термин «социальный капитал» подразумевает под собой совокупность общественных норм и моральных ценностей, разделяемых обществом / организацией / группой, посредством которых сотрудничество внутри общества / организации / группы становится возможным. Изначально П. Бурдьё придавал термину экономический смысл, так, социальный капитал, как и человеческий / материальный (финансовый) и интеллектуальный, рассматривается в разрезе экономического развития организации или государства в целом.

Наиважнейшими регулятивами социальной деятельности служат гражданские ценности и нормы, которые обозначают правила социального поведения, ожидания и стереотипы, регулятивы, всё, что способно регламентировать социальную деятельность индивидов / групп в разрезе ценностей, присущих определённой культуре, укрепляющих стабильность., отвечающей интересам безопасности и стабильного развития общества. Гражданские нормы, разновидностью которых являются не только социальные, но и политические, представляют собой «инструкцию» жизнедеятельности в обществе.

Социальные ценности определяют гражданские нормы, предписывая «правила игры». Закономерным является тот факт, что общественные ценности определяют всеобщую, стратегическую регуляцию поведения, а гражданские создают образцы, определенные установки поведения.

Гражданские нормы, с рычагами управления в качестве поощрения и наказания, имеют социальную основу, отражая интересы людей, формирующихся в социальной сфере, посредством которых формируются социальные, политические и гражданские институты общества, такие как семья, гражданское общество, парламент, государство и т. д. Только соблюдая гражданские, социальные и политические нормы возможно взаимодействие между этими институтами.

Помимо политических норм, социальную деятельность регламентируют нормы общесоциальные: правовые (конституция, законы, государственные и административные нормативные акты) и моральные (предписанные стандартами образцового поведения и культурой). Правовые нормы определяют условия применения юридических норм, санкций, предписывающих «карание» за их нарушение. Эти нормы подкреплены авторитетом государства и наделены силой его органов. Моральные нормы обеспечиваются посредством общественного мнения, морального долга.

Социальные нормы подразделяются на формальные / неформальные, устные / письменные, явные / латентные, а так же на общепринятые принципы социальной деятельности или конкретные образцы общественного поведения: демократию, авторитаризм, тоталитаризм. Кроме того, в социальном действии, как и в социальных нормах, их обусловливающих, находят своё выражение характеристики следующего толка: 
позитивные (предписания), и негативные (табу- запреты).

Субъект следует социальным нормам путем их интернализации (превращения во внутреннюю привычку в процессе социализации), или институализации (включившись в социальную систему общества, применения различных санкций к тем, кто нарушает принятые нормы ).

Нормы, составляющие социальный капитал, включают в себя правдивость, доверие, выполнение обязательств, взаимодействие с другими людьми. Условием успешного взаимодействия является соблюдение моральных ценностей и общественных правил.

Правовые нормы только в связке с социальной поддержкой, способны отвечать потребностям общественного развития, ориентировать на деятельность в интересах общества, представлять одну из форм социального капитала, на основе которой и обеспечивается развитие общества. При этом социальногражданский капитал имеет противоположное влияние на государство, способствуя или препятствуя реализации государственных программ и реформ.

Перед современными правительствами и общественными организациями, стремящимися к стабильно высокому экономическому росту благосостояния граждан, остро стоит вопрос социально-экономической и политической ситуаций. Каковы перспективы человеческого капитала в глобализирующемся мире?

Социально-экономические ценности и политические идеи переоцениваются: человеку необходим не только доступ к ресурсам, но и овладение ими, что позволило бы ему качественно изменить свою жизнь. Налицо возрастание значимости самореализации / самоуважения.

В контексте заявленной темы, мы будем рассматривать социальный и человеческий капитал в качестве потенциальных ресурсов, которые стоило бы использовать для социально-экономического развития, учитывая, что формирование гражданского общества невозможно без социального капитала, - необходимого условия развития гражданской жизни. В Приднестровье, самоопределившемся (непризнанном) государстве, вышеперечисленные проблемы особо актуальны для развития гражданского общества.

Приднестровье начала 1990-х годов и есть тот самый пример социального капитала / общественных связей, посредством которого был реализован классический «общественный договор», который, цитируя Томаса Гоббса, «больше, чем согласие или единодушие. Это реальное единство, воплощенное в одном лице посредством соглашения, заключенного каждым человеком с каждым другим таким образом, как если бы каждый человек сказал каждому другому человеку: я уполномочиваю этого человека или это собрание лиц и передаю ему право управлять собой при условии, что ты таким же образом передашь ему твое право и будешь санкционировать все его действия» [3]. Граждане Приднестровской Молдавской Республики самостоятельно провозгласили и построили государство, реализовав своё право на самоопределение, - факт, которым, безусловно, стоит гордиться и, возможно, ставить в пример в качестве реализации социального капитала.

\section{Литература}

1. http://politcom.ru/9627.html (на дату открытия, 22.05.2019).

2. Бурдье П. Формы капитала // Экономическая социология. 2002. Т. 3, № 5.

3. Гоббс Т. Избранные произведения: в 2 т. Т. 2. С. 127.

4. Коулмен Дж. Капитал социальный и человеческий // Общественные науки и современность. М., 2001. №3.

5. Пэтнам Р. Чтобы демократия сработала. Гражданские традиции в современной Италии. М Пер. с англ. А. Захаров. - М.: Ad Marginem, 1996.

6. Тённис Ф. Общность и общество / Пер. с нем. А.Н. Малинкина // Социологический журнал, 1998. Том. 0. № 3-4. C. C. 206-229. 